\section{Water Research}

Volume 41, Issue 12, June 2007, Pages 2774-2786

http://dx.doi.org/10.1016/j.watres.2007.03.003

(C) 2007 Elsevier Ltd All rights reserved
Archimer, archive institutionnelle de l'Ifremer http://www.ifremer.fr/docelec/

\title{
Microbial impact of small tributaries on water and shellfish quality in shallow coastal areas
}

\author{
P. Riou ${ }^{1}$, J.C. Le Saux², F. Dumas ${ }^{2}$, M.P. Caprais ${ }^{2}$, S.F. Le Guyader ${ }^{2}$ and M. Pommepuy ${ }^{2}$ \\ ${ }^{1}$ Ifremer, Port-en-Bessin, Avenue du Gal De Gaulle, 14520 Port-en-Bessin, France \\ ${ }^{2}$ Ifremer, Centre de Brest, BP 70, 29280 Plouzané, France \\ ${ }^{*}$ Corresponding author: Monique Pommepuy (Monique.pommepuy@ifremer.fr)
}

\begin{abstract}
:
This study aimed to investigate the impact of small tributaries on seawater and shellfish quality in coastal area subjected to brief episodes leading to fecal contamination. Escherichia coli and F-RNAspecific bacteriophages were selected as fecal indicators and astroviruses were chosen as being representative of pathogens in the human population during winter viral epidemics. A two-dimensional hydrodynamic model was built to simulate the current and dispersion in the model domain, which includes areas uncovered at low tide. The model also includes decay rates to simulate microorganism behavior and assess the influence of fecal input on shellfish quality. The originality lies in the fact that specific features of the study area were considered. Modeling results indicate limited particle movements and long flushing times at the back of the bay, where shellfish are farmed. Computational results showed that under normal conditions, i.e. 94\% of the time, when rainfall was less than $10 \mathrm{~mm}$ per day, the sector shows acceptable water quality. These results are in agreement with shellfish concentration measured in the field. Under high flow conditions, high concentrations of fecal indicators and astrovirus were measured in the river and tributaries. The corresponding fluxes were over 50 times higher than under normal weather conditions. The location of the shellfish beds near the coast makes them vulnerable and fecal indicators and viruses were detected in shellfish after short rainfall events.
\end{abstract}

Our modeling approach makes a contribution to shellfish management and consumer protection, by indicating the "risk period" as defined by EU regulations. Molecular development such as viral quantification in conjunction with model developments will help to prevent shellfish contamination and thus provide safer products to consumers and an effective tool for shellfish producers.

Keywords: Modeling; Seawater fecal contamination; E. coli; F-RNA specific; Astrovirus; Shellfish 


\section{INTRODUCTION}

Coastal areas are potentially affected by large and relatively constant inflows from contaminated water sources like rivers or incorrectly treated sewage. This maintains a generally poor water quality and limits activities such as bathing and aquaculture which fall under safety standard requirements (Kay et al., 2005; Lipp et al., 2001; Lees, 2000; E.P.A, 1999). In addition, areas with good water quality can be impacted by pollution during short events (Ackerma and Weisberg, 2003). Several possible causes, such as heavy rainfall, can lead to sewage network breakdowns (Griffin et al., 2003; Le Guyader et al., 2000). Another sporadic source of contamination which increases the fecal load in rivers is agricultural manure spreading (Collins and Rutherford, 2004). However, the characterization of pathogens in shellfish has indicated that the main source is human fecal contamination, and when environmental data have been available, contamination by sewage has often been demonstrated (Le Guyader et al. 2003; Lees 2000). Flooding has also been shown to be responsible for viral contamination in outbreaks and was congruent with the sudden input of multiple NoV strains on an oyster breeding site (Le Guyader et al. 2006). These types of contamination incidents may lead to health problems, closure of farmed areas and their ensuing socio-economic effects (Kohn et al., 1995).

As a consequence of outbreaks over the last century, developed countries have set up regulations concerning the sanitary quality of shellfish growing areas and bathing water. EC Directive 91/492 sets out a classification of harvesting areas by E. coli standards in shellfish ( $<230$ E. coli/100g), and the European Bathing Directive (76/160/EEC) stipulates that water quality must be $500 \mathrm{E}$. coli/100ml. Regulations to protect coastal waters, like the US Clean Water Act (CWA), or the recent European Framework Water Directive (FWD), set quality objectives which could be applied to improve water quality. These regulations address an ecological objective, and must also take "protected areas” into account, among them shellfish growing or bathing areas covered by other Directives.

Catchment-based tools to manage protected areas and budget models have already been developed and applied to the case of bathing waters (Kay et al., 2005). Over the past decade, mathematical models have been developed to investigate the impact of fecal load on marine water quality on American coasts (Streets and Holden, 2003), New Zealand (Collins and Rutherford, 2004), France (Pommepuy et al., 2004; Fiandrino et al., 2003) and Great-Britain 
(Kashefipour et al., 2002). Other models have been able to highlight the factors which could be the source of contamination and to propose solutions for sustainable management (GarciaBarcina et al., 2006; Kay et al., 2005)

Despite the recent development of hydrodynamic modeling of the environment, few simulations of minor incidents have been made, and this is all the more true for the impact of viral water contamination (Pommepuy et al., 2005). Short term deterioration has been observed when small tributaries bring large loads of fecal microorganisms during accidental events (Crowther et al., 2001), but little information exists about the time needed for subsequent water quality recovery. Many microorganisms are highly resistant in the environment. It is well known that E. coli's decay-rate is lower than that of viruses, and that shellfish which are compliant with EU standards could still remain contaminated with viruses for a long time after brief pollution events (Pommepuy et al, 2005; Lees, 2000). Model applications are of great interest to assess the impact of forecast events, especially those leading to pathogen inputs. The information they could provide about beaches or other areas to be closed would be particularly valuable from an economic perspective (Ackerma and Weisberg, 2003). But local characteristics must be taken into account. In France, for example, summer storms are often associated with E. coli contamination, while heavy winter rainfall sometimes coincides with viral diseases and closure of shellfish growing areas, even in class “A” (European directive) areas (Le Guyader et al., 2003; Ifremer's Remi monitoring network data).

The main objective of this study was to investigate the impact of small outfalls on water quality in an area in Normandy, where aquaculture and tourism activities are significant. Using an innovative modeling approach taking the local situation into account, we estimated the behavior of microorganisms (E. coli, F-RNA specific bacteriophages and astrovirus), present in different concentrations in the outfall and whose behavior in the environment differs, on variations in the water quality. The ultimate goal was to assess the sensitivity of shellfish growing areas to local factors leading to water quality degradation. 


\section{MATERIALS AND METHODS}

\section{Study area}

The area studied includes the eastern coast of the Cotentin peninsula, located in the western part of the Bay of Seine (fig. 1a). The total catchment basin covers about $222 \mathrm{~km}^{2}$ (fig. 1b). Two rivers, the Saire in the north and the Sinope in the south, are responsible for the main freshwater runoff. Between these sub-catchments, a coastal sub-catchment $\left(28 \mathrm{~km}^{2}\right)$, is drained by small tributaries, Bonde, Vaupreux and Godey, which flow directly into the shellfish growing area (fig. 1c). The area has a population of approximately 11,300, with a low density of 51 inhab/ $\mathrm{km}^{2}$. A sewage treatment plant (STP), designed for a population of 10,000 discharges the treated water after activated sludge treatment and decantation into the harbor. On the catchment area, farming is mainly devoted to cattle with about 22,200 head on the total watershed. A quarter of the animal population is found on the coast, within $1 \mathrm{~km}$ from the seaside. The other economic activities are tourism and oyster farming. About 14,000 tons of shellfish are grown in the marine area (fig. 1c). The shellfish beds are located in shallow waters and can spend half of the spring tidal cycle out of water because of the tidal range which can reach seven meters during spring tides and four meters during neap tides here.

\section{The hydrodynamic model}

\section{Modeling approach}

The mathematical model accounts for advection, dispersion, and microbial die-off. The flow dynamics are governed by the Navier-Stokes set of equations under the Boussinesq and hydrostatic approximations (Cugier and Le Hir, 2002). The 2-D horizontal model solves the St Venant equations:

Advection equations:

$$
\begin{aligned}
& \frac{\partial u}{\partial t}+u \frac{\partial u}{\partial x}+v \frac{\partial u}{\partial y}+g \frac{\partial \zeta}{\partial x}-f v=\varepsilon\left(\frac{\partial^{2} u}{\partial x^{2}}+\frac{\partial^{2} u}{\partial y^{2}}\right)-g \frac{u \sqrt{u^{2}+v^{2}}}{k^{2} H^{4 / 3}}-\frac{\partial P a}{\partial x}-\frac{\tau_{x}}{\rho H} \\
& \frac{\partial v}{\partial t}+u \frac{\partial v}{\partial x}+v \frac{\partial v}{\partial y}+g \frac{\partial \zeta}{\partial y}-f u=\varepsilon\left(\frac{\partial^{2} v}{\partial x^{2}}+\frac{\partial^{2} v}{\partial y^{2}}\right)-g \frac{v \sqrt{u^{2}+v^{2}}}{k^{2} H^{4 / 3}}-\frac{\partial P a}{\partial y}-\frac{\tau_{y}}{\rho H} \\
& \text { with } \quad u=\frac{1}{H} \cdot \int_{-d}^{\zeta} u \cdot d z \text { et } \quad v=\frac{1}{H} \cdot \int_{-d}^{\zeta} v \cdot d z
\end{aligned}
$$


Continuity equation: $\quad \frac{\partial \zeta}{\partial t}+\frac{\partial(H u)}{\partial x}+\frac{\partial(H v)}{\partial y}=0$

where: $\zeta=$ water surface elevation; $u=$ velocity component in $\mathrm{x} ; v=$ velocity component in $\mathrm{y}$; $d=$ depth ; $H=$ water column $(\mathrm{d}+\zeta) ; f=$ Coriolis parameter ; $k=$ Strickler coefficient; $\gamma=$ fluid viscosity; $g$ = acceleration of gravity.

The equation systems are solved by MARS-2D code (Salomon and Pommepuy, 1990; Orbi and Salomon, 1988). The model's area consists of $4,800 \mathrm{~km}^{2}$ with a horizontal computation grid made up of 360,000 meshes (mesh size: 75 m x 75 m).

The study area never exceeds 30 meters in depth and vertical water mixing is done by strong currents. Thus, a bi-dimensional horizontal model was assumed to be an appropriate tool for the hydrodynamic part of this study. To confirm this hypothesis and to validate the model, different measures were performed in the field. Boat trials were carried out on different transects from the coast to the outside of the domain, by measuring local tidal currents with an Acoustic Doppler Current Profiler (broad band 1200 kHz R.D. Instrument). Salinity and temperature were recorded in different model sub-domains - locations 1, 2, 3 and 4 - for several weeks each, evaluating variations and possible stratification during winter and spring periods (TPS Micrel/Sensor35M).

\section{Flushing time}

We focused on the flushing time, based on the continuously stirred reactor (CSTR) concept described in Monsen et al. (2002). The main assumption of the CSTR model is that any mass introduced in the system is instantaneously mixed over the whole domain. If a given mass is input at $\mathrm{t}=0$ (resulting in an initial concentration $\mathrm{C}_{0}$ ), no further mass will be introduced in the system after $\mathrm{t}=0$. Moreover, if the flow and the volume of the CSTR remained constant, Thomann and Mueller (1987) showed that the concentration within the CSTR develops as $C(t)=C_{0} e^{-\frac{t}{T_{f}}}$ where $T_{f}$ is the flushing time. The CSTR flushing thus defined reflects the average amount of time the mass spends in the system.

We defined four sub-areas, as CSTR. They were about $4 \mathrm{~km}^{2}$ each and were noted A, B, C and D (fig. 1c). In each sub-area the flushing time $\left(T_{f}\right)$ was computed as follows: 


$$
\begin{aligned}
T_{f}=\frac{\int_{m_{0}}^{0} t * d m}{\int_{m_{0}}^{0} d m} \quad \text { where } \\
\qquad\left(m_{\text {totale }}=\sum_{i=1}^{n} C(i) * V(i)\right)_{t}
\end{aligned}
$$

$\mathrm{m}$ : total mass of the tracer in the sub-area [unit] $\mathrm{n}$ : mesh number in the sub-area $\left[100 \mathrm{~m}^{2}\right]$ $\mathrm{C}(\mathrm{i})$ : tracer concentration in mesh « $\mathrm{i}$ » [unit/ $\mathrm{m}^{2}$ ] $\mathrm{V}(\mathrm{i})$ : water volume in mesh « $\mathrm{i} »\left[\mathrm{~m}^{2}\right]$

The $T_{f}$ was computed for following conditions: mean tide, real tide variation (alternately high and neap tides), without and with winds (from south-west, north-east and south-east respectively at speeds of 7,5 and $5 \mathrm{~m} \cdot \mathrm{s}^{-1}$ ).

\section{Microbiological model}

The microbial model integrates a term summarizing all the biological aspects of microorganisms and described by a simple first-order reaction. Equations describing the fate of bacteria or viruses were the same for any dissolved constituent except for the T90 (time needed for the initial concentration to decrease of one log), which takes the behavioral aspect of these living organisms into account.

transport equation

$$
\frac{\partial H C}{\partial t}+\frac{\partial\left(H\left(u C-K_{x} \frac{\partial C}{\partial x}\right)\right)}{\partial x}+\frac{\partial\left(H\left(v C-K_{y} \frac{\partial C}{\partial y}\right)\right)}{\partial y}=S-\text { Deca } y
$$

Where: $\mathrm{C}=$ concentration; $\mathrm{k}_{\mathrm{x}}$ and $\mathrm{k}_{\mathrm{y}}=$ diffusive coefficient; $\mathrm{S}=$ source term; Decay is the sinking term for C. The decay term is related to the T90 as follows:

decay $=\frac{\log 10}{T 90} \mathrm{CH}$ where the log is the natural logarithm.

The T90s used in the model are presented in table 1 with the other parameters used for simulations. They were selected from a literature review and are dependent on the season, as previously reported (Pommepuy el al., 2005).

Boundary conditions at the coast: the input of the two rivers and the tributaries was put into the model, taking permanent flows and/or overflow into account. Tidal variations (spring/neap tide sequences) and wind effects were simulated. The hydrodynamic model accounts for fluxes even if the outfall is located on the tidal flat. When, in the low tide situation, there is no water in the mesh, the flux injection is not lost. These fluxes accumulate in the mesh during the low tide and are dispersed in the sea during the next high tide. Boundary conditions out 
side the model are provided by nested models already running in this area (Ifremer's Mars models). These models calculated the water height, current speed and direction as a function of tidal conditions at the boundary of our model. Finally, we assumed that the reintroduction of pollutant leaving the domain was negligible due to the strong hydrodynamic effect at the boundaries.

\section{Microbial study}

Sampling trials: the study started in March 2001, after a fecal contamination alert in the sector. Sampling was carried out until March 2004, to evaluate fecal contamination and validate the model simulations. Monthly samples were collected to include different weather and hydrodynamic conditions. The rivers and small tributaries (Bonde, Vaupreux and Godey) and four shellfish beds were sampled (fig. 1c). Seven small outfalls located in the area and flowing into the bay were also sampled during heavy rainfall events (16 October 2002, 2 July 2003 and 12 January 2004). The flow rate was measured in rivers and tributaries using flowmeter sensors (OTT type, with a C2 or C3 screw depending on the depth and the current speed). Forecast data were obtained from Météo-France station of Carteret, which is representative of weather conditions for the upstream drainage area and marine coastal sector. Analyses

Fecal indicators (E. coli and F-RNA specific bacteriophages) and astrovirus were selected to monitor the contamination of the shellfish area. The astrovirus was chosen as a model for human enteric viruses, since it is often detected in winter urban water sewage as a function of the input of viral gastro-enteritis in the population.

Water and oyster analyses: the water was directly analyzed, while the oysters (Crassostrea gigas) were washed and shucked before being analyzed for E. coli and F-RNA specific bacteriophages upon arrival in the laboratory. E. coli was assessed using the ISO 9308-3 technique in water and the NF V 08-106 impedancemetry technique in shellfish (Dupont et al., 2004). F-RNA specific bacteriophages were detected using the NF- ISO 10705-1 technique. The results are expressed for E. coli and bacteriophages respectively in colonyforming units per $100 \mathrm{ml}(\mathrm{cfu} / 100 \mathrm{ml})$ and forming units per $100 \mathrm{ml}(\mathrm{pfu} / 100 \mathrm{ml})$ in water and per100g in shellfish.

Astroviruses were detected after polyethylene glycol (PEG) 6000 (Sigma St Quentin, France) precipitation from $40 \mathrm{ml}$ of water samples or $1.5 \mathrm{~g}$ of dissected shellfish digestive tissues (corresponding to about 4 oysters). Nucleic acids were extracted and purified as described in 
Le Guyader et al. (2000). The quantity of astrovirus was estimated by real-time, one step RTPCR. The primers were adapted from Le Cann et al. (2004). Astroviruses were detected on 5 $\mu \mathrm{l}$ of nucleic acid extracts in presence of $200 \mathrm{nM}$ of each primer and Fam-Tamra labelled probe, using the Platinum quantitative RT-PCR thermoscript on-step system (Invirtogen, France). According to the instructions given by the manufacturer, the RT was performed at $50^{\circ} \mathrm{C}$ for $30 \mathrm{~min}$, denaturated for $5 \mathrm{~min}$ at $95^{\circ} \mathrm{C}$ and amplification was achieved by 50 cycles of $95^{\circ} \mathrm{C}$ for $15 \mathrm{~s}$ and $55^{\circ} \mathrm{C}$ for 1 min., using an ABI Prism 7000 SDS detector (Applied Biosystems, France) in a 96-well format. An RNA standard, quantified by spectrometry and confirmed by Ribogreen (Interchim, Montluçon, France) was used in all amplification action at different dilutions from $1.310^{9}$ copies/ml to 1.3 copies/ml (Le Cann et al., 2004). The number of genomes was calculated from real-time fluorescence measurements from the cycle thresholds (CT) value, according to the CT values of the standard curve. Two negative controls were included in each reaction, and all the samples were tested twice by amplification. The results are expressed in Gequi/100ml in water and Gequi/100g for shellfish.

\section{Simulation of river and small tributary impacts}

From meteorological data obtained from Météo-France, we calculated the average fluxes for all streams under winter and summer conditions and for rainfall events. Normal conditions were defined as less then $10 \mathrm{~mm}$ cumulative rainfall over a 24-hour period and overflow conditions corresponded to punctual events with rainfall exceeding $10 \mathrm{~mm} \cdot \mathrm{d}^{-1}$. Then fluxes for E. coli, bacteriophages and astrovirus were calculated for model simulations (Table 1).

We ran the model under different fluxes, wind and hydrodynamic conditions. A continuous and constant load discharge was first simulated. Stabilization of the system and concentrations was observed after 12 tidal cycles. After stabilization, we introduced the storm water input and calculated the average concentration after 12 hours of a simulated heavy load. The average concentration of pathogens was calculated for each mesh when the water height exceeded $50 \mathrm{~cm}$.

\section{Estimation of shellfish quality}

Shellfish contamination was estimated from pathogen concentration calculated by the model. Shellfish are filter feeders, and thus concentrate pollutants by feeding. We chose a shellfish/water pathogen concentration ratio of 30. This value is a compromise based on data 
from literature (Anonymous, 1996; Burkhardt and Calci, 2000;). The calculated concentrations in shellfish were compared with those obtained under the same conditions in the field. Thus, microorganism concentrations calculated under "normal conditions" from our model were compared with concentrations measured in gathered shellfish when rainfall was $<1010 \mathrm{~mm} . \mathrm{d}^{-1}$ for several days. Similarly, "storm event” calculations were compared with those measured in the field after a similar rainfall event.

\section{RESULTS}

\section{Hydrodynamic features of the studied area and flushing times}

The tidal current and water height validation obtained with the 2D model are in agreement with in situ measurements. The hydrological measurements show that the water column is always homogeneous as suggested by the low fresh water inputs and Simpson's thermal stratification index (Simpson and Humber, 1974). Most of the time, no thermal salinity or stratification is observed in the model domain (fig. 2). During a very short period of time, salinity stratification was measured in the north of the domain, when the Saire river's flow dramatically increased. However, a 2D horizontal model is assumed to be realistic in simulating the impact of small tributaries, because the Saire does not impact the targeted shellfish area (fig. 1c). For this reason, not all the data concerning this river are reported here.

Lagrangien simulations give information on the behavior of particles starting from any location of the model during mean tide (fig. 3). For instance, a particle starting at high tide outside the shellfish areas (location 5, fig. 3a) is carried towards the north by ebb currents, then returns to the south with the flood flow. With the next four tides, it has a residual transport of a few kilometers towards the north. Under the same conditions, a particle dropped at location 3 has a similar trajectory at location 5 , as well as a residual transport towards the north (fig. 3b). On the contrary, the model shows that a particle starting at location 1 under the same conditions would remain in the area during the next four high tides (fig. 3c).

The model calculates the flushing time $\left(T_{f}\right)$ for sub-areas (A, B, C and D) for different tides (spring tide, neap tide, mean tide). Flushing time is a function of the volume of the sub-areas, and comparison between two sub-areas allows local sensitivity to contamination, with respect to the other areas, to be estimated. Results indicate a large variation depending on the sub- 
domain, the tidal current and wind conditions (fig. 4). For example, the longest $T_{f}, 75$ hours, was obtained in sub-area A. This $T_{f}$ is two or three times higher than the other $T_{f}$ domains and 7 times greater than the $T_{f}$ calculated in outlying sub-domain $\mathrm{D}$. The flushing time decreases from north to south (from A to C). The prevailing south-west wind in the Bay of Seine, blowing $70 \%$ of the time at $7 \mathrm{~m} . \mathrm{s}^{-1}$, lowers the $T_{f}$ to 15 hours or less depending the subdomains. The south-easterly wind has no influence on sub-areas $\mathrm{A}$ and $\mathrm{D}$, but lower $T_{f}$ in $\mathrm{B}$ and C.

\section{Fecal contamination and model simulations}

E.coli and F-RNA concentrations measured in tributaries and in river Sinope during normal and overflow conditions are presented in Table 2. Whereas no significant difference in fecal concentrations was observed between seasons (data not shown), the cumulative rainfall had a profound effect on pathogen concentrations. When the rainfall amount was under $10 \mathrm{~mm} . \mathrm{d}^{-1}$, F-RNA phage concentrations were about 10 times less than those of E. coli. When the rainfall amount exceeded $10 \mathrm{~mm} \cdot \mathrm{d}^{-1}$, E. coli concentrations increased up to 50-fold, while bacteriophage concentrations remained more or less stable. At the same period, astrovirus concentrations ranged from $<100$ to $2.210^{5}$ Gequi/100ml in the river and from $710^{2}$ to $110^{5}$ Gequi/100ml in the tributaries which collected urban waters.

The sewage treatment plant releases treated water into the harbor to the north of the studied domain (fig.1). Nevertheless, bypassing of untreated water was observed in the small tributaries discharging into the bay (sub-area A) during one of the overflow events $\left(1^{\text {st }}\right.$ December 2004). Concentrations of $10^{6}$ E. coli cfu/ $100 \mathrm{ml} 10^{5} \mathrm{PFU}$ phages $/ 100 \mathrm{ml} ; 310^{6}$ Gequi/100ml astroviruses were measured in an outfall located at the back of the bay.

Fecal fluxes were calculated for E. coli, bacteriophage and astrovirus for the selected conditions (rainfall $<10 \mathrm{~mm} . \mathrm{d}^{-1}$ and $>10 \mathrm{~mm} . \mathrm{d}^{-1}$ ) (Table 1). There was very little seasonal variation in the average fluxes; the difference between the average fluxes for E. coli and FRNA phages between summer and winter periods was generally less than a log. Maximum $E$. coli fluxes were observed in the Sinope river, which represented $86 \%$ of $E$. coli fluxes and 75 $\%$ of phage fluxes under normal rainfall conditions. The E. coli fluxes were 50 to 100 times higher under overflow conditions compared to normal periods. Under overflow conditions, astrovirus fluxes were estimated to be on average about $10^{12}-10^{14}$ Gequi/12h depending on the tributary or the river. 
The winter overflow situation (rainfall $>10 \mathrm{~mm} . \mathrm{d}^{-1}$ ) was simulated, along with the horizontal distribution of E. coli impacts from the Sinope and the other tributaries during mean tide. Figure 5 show the representative extension of the outfall plumes and their impact on $E$. coli water quality where shellfish are grown at different hours of the tide (high tide: fig. 5a; three hours after high tide: fig. 5b; low tide: fig. 5c). The model simulation distinguished three areas:

- The north of the shellfish was exclusively under the influence of the Bonde, Vaupreux and Godey tributaries, as well as the small other tributaries in action during winter rainfall even. The Vaupreux and Bonde contribute to more than $90 \%$ of location 1 contamination, because of the proximity of the outfall at high tide (less than $500 \mathrm{~m}$ ). Contaminated plume, with a small dilution, reached location 2 at 3 hours after high tide. This last location was especially affected at low tide. During spring ebb tides, shellfish beds were bathed by the contaminated waters transported and poorly diluted in the shallow waters (data not shown).

- The south part of shellfish beds (location 4) was mainly impacted by the Sinope (until 100 $\%)$, whose plume reached the shellfish at high tide with some dilution (E. coli concentration from 1 to $10 \mathrm{ufc} / 100 \mathrm{ml})$. During ebb tide, higher E. coli concentrations (100-1000/ufc/100ml) could reach this location.

- The shellfish area located between locations 2 and 3 was free from the plume's contamination. Location 3 received some contaminated water from the river Sinope (1-10 ufc/100ml), depending on the tide.

The model also computed the impact during spring or neap tides, with and without winds from different directions (data not reported here). During neap tides, the extension of the plumes were less than those shown in fig. 5, but the concentrations could be higher than during mean tides, especially on the north of the shellfish area. During spring tides, the plume reached this location in a very short time, less than one hour, with poorly diluted waters.

\section{Water quality recovery}

The effect of a punctual raw water overflow from tributaries impacting location 1 is presented in fig. 6. These outfalls are located within less than $1 \mathrm{~km}$ from this site. The model simulated 12 hours of overflow, with maximum fluxes in E. coli, bacteriophages and astroviruses. Before the input, the concentration at location 1 was very low under average conditions. Immediately after the overflow started, i.e. in less than one hour, the poorly diluted sewage 
overflow reached location 1 with high values in fecal concentrations. After stopping the input, the decrease in concentrations was observed over the following tides. The concentrations decreased over time as a function of dilution and T90s. For E. coli, less than 5 days, was necessary to decrease the concentration to below $0.0001 \mathrm{Unit} / \mathrm{m}^{3}$. For bacteriophages, this concentration was reached in more than 9 days, and for astrovirus, the recovery time was up to two weeks, due to the high persistence of viruses in the environment.

\section{Impact of fecal input on shellfish contamination}

The fecal contamination measured in shellfish for the conditions simulated by the model (rainfall $<$ or $>10 \mathrm{~mm}^{-1} \mathrm{~d}^{-1}$ ) are presented in tables 3, 4 and 5. For an average uniform daily input of $E$. coli simulation during neap tide, the water concentration in the all area is less than $2 \mathrm{cfu} / 100 \mathrm{ml}$ in summer and less than $8 \mathrm{cfu} / 100 \mathrm{ml}$ in winter (table 3). Applying the ratio 30, shellfish contaminations were then calculated from water concentrations. Result interpretation takes the analytical variability into account (Anonymous, 2003), thus, we considered that, most of E. coli concentration are consistent with those measured under the same conditions in summer in field ( $<100 \mathrm{ml} / 100 \mathrm{~g}$, analysis threefold for E. coli). The same order of magnitude was found in winter at location 2, between calculated and measured shellfish contamination, while a few difference was observed at the other locations (less than a factor 2). In table 4, FRNA concentrations were reported for winter season, under same conditions (neap tide, rainfall amount less than $10 \mathrm{~mm} \cdot \mathrm{d}^{-1}$ ). The range between minimal and maximal concentrations for naturally-contaminated shellfish is in accordance with calculated shellfish contamination (same order of magnitude, which is compatible with the analytical variability, Anonymous 2003). However, maximal concentrations measured in the field were found to be up to 30 times higher than calculated at locations 2 and 3.

Shellfish contamination during neap tide and an overflow winter simulation (rainfall $>10 \mathrm{~mm} . \mathrm{s}^{-1}$ ), are reported in Table 5 . The results obtained by the model were in accordance with E. coli, bacteriophage and astrovirus concentrations measured in shellfish during the winter overflow event at location 1 (less than $0.5 \log$ for astrovirus concentration). This location shows the highest concentration of any microorganism of all the measured locations, because outfall proximity. Shellfish from locations 2 and 3, situated at a greater distance from the outlets, were less contaminated. For some of the locations, calculated and measured contamination for E. coli (location 3) and bacteriophages (location 2 and 4) did not differ 
substantially. However, at the other locations, the calculated values differ from the actual measurements by a factor of 10 .

\section{DISCUSSION}

Different approaches are proposed in the literature to measure the influence of dynamic processes on the aquatic systems subjected to contamination (Abdelrhuman, 2005; Delhez et al., 2004). Our modeling approach used currently applied concepts and equations. However, unlike most similar studies, we considered the specific features of our study area. Shellfish are grown in shallow waters located less than $1 \mathrm{~km}$ from small sewer outfalls. Moreover, the tidal range of at least $7 \mathrm{~m}$ during spring tides needs to take fecal input in account, even for locations on the tidal flat. Furthermore, we included viral contamination in our simulations. A few applications have been reported for viral contamination (Pommepuy et al., 2005), while models are currently used to evaluate the water quality and the sensitivity of estuaries subjected to E. coli contamination (Kay et al., 2005; Kashefipour et al., 2002; Fiandrino et al, 2003;). We focused on areas where the depth does not exceed $10 \mathrm{~m}$ with a homogeneous water column.

The model showed that particle trajectories mainly run towards the north, except for those starting in the shellfish area. These results are consistent with Salomon and Breton (1993), which demonstrated that, near the coast of the East Cotentin peninsula, the residual tidal current is oriented towards the north. More interestingly, the model shows that, when starting in the bay, the particles are trapped and stay near the coast for a long time. Thus, local input of contaminants could be of major importance as regards the quality of the shellfish area. Several approaches have been applied to estimate transport time (Abdelrhman, 2005). Three methods were compared by Monsen et al. (2002) based on age, residence time and flushing time $\left(T_{f}\right)$. These allow orders of magnitude to be estimated and each method corresponds to a time scale (Abdelrhman, 2005). To compare different sectors in our study area, the $T_{f}$ method was found to be relevant according the time scale (a several hours to several days). The shorter $T_{f}$ was found close to the coast and was two or three times lower than the other subareas. Moreover, in our results, the $T_{f}$ of a given sub-domain may be several times higher due to windy conditions. Delhez et al. (2004), working on a larger area (Bay of Seine), reported 
also variability which was found to be depend on the season. This authors demonstrated that winter circulation induces low flushing times, while the decrease of the river flow in spring and summer was responsible for longer flushing times.

As expected, the sensitivity of the sector to contamination was emphasized by the presence of small tributaries which overflowed with raw water during short periods. During normal periods, with rainfall amount less than $10 \mathrm{~mm}$ per day, fecal concentrations in the inputs corresponded to acceptable urban loads after treatment and were in accordance with those found in river or in treated urban water (Garcia-Barcina et al., 2006; Rose et al., 1996). However, when measuring the contamination during heavy rainfall episodes, large fecal concentrations were found in the small tributaries. The concentrations were comparable with poorly treated water, for example, those measured after primary sewage treatment (Rose et al., 1996). Moreover, the astrovirus concentration in the same conditions corresponded to those found by Le Cann et al. (2004) in raw waters. On the contrary, the F-RNA phages concentrations were relatively stable between dry and wet conditions, demonstrating the possible prevalence of rural runoff (Brion et al., 2002).

When the amount of rainfall was more than $10 \mathrm{~mm}$ per day, the sampling effort was stepped up to obtain data from all the small tributaries collecting urban and runoff waters. During our four-year study, $10 \mathrm{~mm} . \mathrm{d}^{-1}$ was exceeded only twice, while during the years from 1997-2004, the Météo-France weather station at Carteret reported a 6.41\% occurrence of heavy rainfall in Normandy. Despite relatively low occurrences, our observations indicated that these short events may lead to dramatic overflows in the small tributaries which directly discharge into the shellfish area. Even though these fluxes were lower than those measured in the Sinope river, they had significant impact on shellfish quality, especially in the north of the area.

The drop in contamination in seawater was dependent on tides and flushing times, but T90s also acted upon decontamination (Noble et al., 2004). As demonstrated by authors, the T90 depends on different physical parameters including mainly sunlight irradiation, temperature, salinity and suspended solids (Pommepuy et al., 2005). The T90s also depend on the microorganisms. A previous study in Normandy indicated that E. coli's T90 may vary from 24 to 48 hours (Pommepuy, unpublished data). These times concurred with those found elsewhere (Pommepuy et al., 2005). Even though very little information exists concerning bacteriophage and viral behavior, there are indications that they are more resistant to adverse 
conditions in the environment than E. coli (Lees, 2000). Thus, we allowed 96 hours for T90 phages in summer and 168 hours in winter, the latter to account for high resistance at low temperature. For astroviruses, mainly excreted in winter, T90s were greater, equaling 336 hours according to published results (Loisy el al., 2005).

The model calculated that the time to reach the shellfish bed (location 1 and 2) was very short - less than 3 or 6 hours -, and thus, the biological factors responsible for the bacterial decrease were not efficient enough to play a role in decreasing the plume contamination. Moreover, in the same area, physical dilution in seawater during mean tides was 500 times lower from the outlet of tributaries to the north of the shellfish area, and its sole effect cannot decrease dilution. This is of the greatest sanitary importance, since shellfish tissue is contaminated within 30 minutes when mollusks are subjected to tainted seawater (Plusquellec et al., 1990). The situation during spring tides and ebb tide, could also be adverse for shellfish area quality, because the plume reached beds in a shorter time (less than one hour), with poorly diluted waters.

Depending on the wind's effect on the particle flushing times, the most favorable conditions for water quality of shellfish beds, especially in the bay, were winds blowing from the southwest. This is the prevailing wind direction in the region and could lead to better dilution of contaminated water during events of heavy rainfall. The southern part of the area was mainly impacted by the Sinope, whose plume reached the shellfish at high tide with some dilution. Because the flushing time was lower than those in the north, the contamination from the river Sinope would be evacuated more quickly.

The model also allows a simulation of the time needed for water quality recovery. For our purpose which was to determine the sensitivity to contamination, the comparison between the physical factors and T90 was important for assessing the capacity of the sector to evacuate pollution. Salomon and Pommepuy, (2000) showed that, in an estuary submitted to high tidal regimes, physical mechanisms were much more important than the T90 for reducing sanitary risk. These conditions were also found here in the outer bay, due to a greater capacity for dispersion. Interestingly, close to the coast, the role of T90 was more important than physical factors to decrease the contamination. And thus, the recovery of water quality in term of $E$. coli was faster than for the bacteriophages or virus. These results also clearly demonstrated 
the poor relationship between fecal indicators and viral contamination, as reported in literature (Lees, 2000; Le Guyader et al., 2000).

We also used the end products of the model - the calculated water concentrations -, to predict shellfish contamination. In fact, health officials have traditionally used $E$. coli to monitor the safety of water or shellfish quality. The efficiency of the model to predict shellfish contamination was assessed by comparing the calculated concentration with those obtained in the field. We decided to apply a ratio concentration between shellfish and water contamination equal to 30 as a compromise on published data from relatively scarce existing information (Burkhardt et al., 2000; Anonymous, 1996). Divergences between calculated and measured shellfish concentrations were observed. According to the variability and the threshold of biological analyses (Anonymous, 2003), we considered the E. coli calculated concentrations by the model as acceptable. Concerning winter phage simulations, different hypotheses could explain the divergences when observed. One reason might lie in an underestimation of calculated fluxes from the rather weak concentrations measured in the rivers during sampling trials. Nevertheless, such low concentrations have already been found by several authors (Brion et al., 2002). Turner and Lewis (1995) also found an average FRNA concentration in waters which was about 10 times less than the E. coli concentrations. High remaining phage concentrations of this type were also observed in oysters when temperatures fell between 12 and $16^{\circ} \mathrm{C}$ (Kator \& Rhodes, 2001). These temperatures are often observed in this area. Finally it is possible that the concentration ratio between shellfish and water used in the simulations was too low. Burkhardt et al., 2000reported large variation in concentration rates in oysters located in a sewage-impacted estuary.

To assess the EU Directive 91/492 requirements concerning the classification of shellfish growing areas in the studied area, the information provided and predicted by the model is of the greatest importance in order to manage the risk. Currently, the European classification is based on fecal shellfish concentrations, contrary to the US, where recommendations are made on water quality. The model demonstrated that under normal conditions, i.e. $94 \%$ of the time, the sector was found to correspond to class A, according to EU regulations (ED/91/492/EEC), as assessed by Ifremer's Remi monitoring network. This also confirmed that the E. coli fluxes, supplied to the model under "normal" condition, were realistic. Nevertheless, the location of the shellfish beds near the coast made them vulnerable, during rare or short periods of rainfall events. The combination sewer overflows receiving rainfall water, untreated wastewater and 
run-off during high precipitation events, were sources of fecal contamination and seriously impacted the shellfish area. These effects are in agreement with published results for other coastal areas (Griffin et al., 2003; Lipp et al, 2001; Miossec et al, 1998). These events are of the utmost importance, especially due to the persistence of microorganisms in shellfish.

Shellfish quality recovery is longer than in water because of the oyster's physiology and the survival of microorganisms in the tissues (Kingsley and Richards, 2003). When temperatures are lower than optimal (i.e. $18^{\circ} \mathrm{C}$ for Crassostreas gigas, according to Bougrier et al., 1995), the shellfish lower their respiration and food uptake activities. During winter, the coastal seawater temperature in Normandie is lower than $12^{\circ} \mathrm{C}$. Under those conditions, depuration takes a long time, especially for viruses to be eliminated (Loisy et al., 2005). Viruses can be trapped in shellfish tissues by ionic bonding to mucus, mainly produced during the winter months (Burkhardt et al., 2000), or by specific binding to cellular receptor (Le Guyader and al., 2006). Thus, viral contamination in shellfish after a winter rainfall event could lead to persistence of poor shellfish quality for several weeks (Miossec and al., 1998).

\section{CONCLUSION}

Our modeling approach makes a contribution shellfish risk management and consumer protection, by indicating the "risk periods" under EU regulations. The model indicates the possible impact of rainfall events and viral input from epidemics in the population on shellfish quality. It furthermore indicates the sensitivity of water quality to fecal contamination, even in class-A harvesting areas. The respective roles of dilution and biological factors were discussed, based on recent knowledge about viral contamination and behavior in sewage, seawater and shellfish, introducing quantitative data on viruses when possible to validate the hypotheses.

Nevertheless, our study remains an initial approach and the model's quality estimation must be improved. For instance, better estimation of $\mathrm{T}_{90}$, especially for viruses, must be found and field measurements are required for more precise information concerning the concentration ratios for shellfish and water contamination. Advances in molecular detection and especially in quantification of pathogens will contribute to assessing the viral shellfish risk. Thus, the 
recently published data from real time PCR assays are promising to obtained data bases to run model and simulate realistic environmental events. Once improved, these models could help assess how efficient possible strategies would be in improving shellfish harvesting areas.

\section{Acknowledgments}

This work was funded by Agence de l'Eau Seine-Normandie, Conseil Régional de Basse Normandie, Conseil Général de la Manche, Direction Départementale de l’Action Sanitaire et Sociale de la Manche, Section Régionale de la Conchyliculture Normandie-Mer du Nord, Ifremer and European Community (IFOP grants). The authors thank Anne Jansens (SRCNdN) and Ronan Le Goff (Ifremer), who coordinated the project. S. Parnaudeau, C. Le Mennec, L. Lamor and F. Maheux are thanked for performing analyses and sampling. We thank Ane Langen and Janet Carnot for reviewing the paper. Thanks also to St VaastQuetehou Urban Council, Direction de l'Equipement and Quettehou STP team for their collaboration during the project life 


\section{References}

Abdelrhman, M.A., 2005. Simplified modelling of flushing and residence times in 42 embayments in New England, USA, with special attention to Greenwich bay, Rhode Island. Estuarine, Coastal Shelf Sci. 62, 339-351.

Ackerma, D., Weisberg, S.B. 2003. Relationship between rainfall and beach bacterial concentrations on Santa Monica Bay beaches. Journal Water and Health, 2, 85-89

Anonymous, 1996. Report on the equivalence of EU and US legislation for the sanitary production of live bivalve mollusks for human consumption. EU scientific Veterinary Committee Working Group on faecal coliforms in shellfish, August 1996.

Anonymous, 2003. Report (WD Sanco/58/2003) upon measurement uncertainties in microbiological analyses with a special reference to uncertainties linked to the proposed microbiological criteria in the document Sanco 4198/2001, revision15).

Bougrier, S., Gairon, P., Deslou-Paoli, J. M, Bacher, C., Jonquères, G., 1995. Allometric relationships and effects of temperature on clearance and oxygen consumption rates of Crassostrea gigas. Aquaculture. 1-2: 134-154

Brion, M., Meschke, J.S., Sobsey, M.D., 2002. F-specific RNA coliphages: occurrence, types, and survival in natural waters. Water Res. 36, 2419-2425 G.

Burkhardt, W.III., Calci, K. R., 2000. Selective accumulation may account for shellfishassociated viral illness. Appl. Environ. Microbiol. 66, 1375-1378.

Collins, R., Rutherford, K., 2004. Modelling bacterial water quality in streams draining pastoral land. Water Res. 38, 700-712.

Crowther, J., Kay, D., Wyer, M.K., 2001. Relationships between microbial water quality and environmental conditions in coastal recreational waters: the Flyde coast. UK., Water Res. 17, 4029-4038

Cugier, P., Le Hir, P., 2002. Development of a 3D hydrodynamic model for coastal ecosystem modelling. Application to the plume of the Seine river (France). Estuarine Coastal. Shelf Sci. 55, 673-695.

Delhez, E.J.M., Heemink, A.W., Deleersnijder, E., 2004. Residence time in a semi closed domain from the solution of an adjoint problem. Estuarine Coastal Shelf Sci. 61, 691-702. 
Dupont, J., Dumont, F., Menanteau, C., Pommepuy, M., 2004. Calibration of the impedance method for rapid quantitative estimation of Escherichia coli in live marine bivalve molluscs. J. Appl. Microbiol. 96, 894-902.

E. P. A., 1999. Review of potential modeling tools and approaches to support the BEACH program, Contract N 68-C-98-010 US EPA -823-99-002, 68p and annexes.

Fiandrino, A., Martin, M., Got, P., Bonnefont, J.L., Troussellier, M., 2003. Bacterial contamination of Mediterranean coastal seawater as affected by riverine inputs: simulation approach applied to a shellfish beeding area (Thau lagoon, France). Water Res. 37, 17111722.

Garcia-Barcina, J.M., Gonzalez-Oreja, J.A., De la Sota, A. 2006. Assessing the improvement of the Bilbao estuary water quality in response to pollution abatement measures. Water Res., 40, 951-960.

Griffin, D.W., Donaldson, K.A., Paul, J.H., Rose, J.B., 2003. Pathogenic Human Viruses in Coastal Waters. Clinical Microbiol. Review, 16, 129-143.

Kashefipour, S.M., Lin, B., Harris, E., Falconer, R.A., 2002. Hydro-environmental modeling for bathing water compliance of an estuarine basin, Water Res. 36, 1854-1868.

Kator, H., Rhodes, M.W., 2001. Elimination of feacal coliforms and F-specific RNA coliphage from oysters (Crassostrea virginica) relaid in floating containers. J Food Protec. 64, 796-801.

Kay, D., Wyer, M., Crowther, J., Stapleton, C., Bradford, M., McDonald, A., Greaves, J., Francis, C., Watkins, J., 2005. Predicting faecal indicator fluxes using digital land use data in the UK's sentinel water framework Directive catchment: The Ribble study. Water Res.

Kohn, M.A., Farley, T.A., Ando, T., Curtis, M., Wilson, S.A., Qi, J., Monroe, S.S., Baron, R.C., McFarland, L.M., Glass, R.I., 1995. An outbreak of Norwalk virus gastroenteritis associated with eating raw oysters. Implications for maintaining safe oyster beds. J. American Assoc. 273, 466-471.

Le Cann, P., Ranarijaona, S., Monpoeho, S., Le Guyader, F., Ferre, V., 2004. Quantification of human astroviruses in sewage using real-time RT-PCR. Research in Microbiology. 155, $11-15$.

Lees, D. N., 2000. Viruses and bivalve shellfish. Int. J. Food Microbiol. 59, 81-116.

Le Guyader, F.S., Neill, F.H., Dubois, E., Bon, F., Loisy, F., Kohli, E., Pommepuy, M., Atmar, R.L., 2003. A semi-quantitative approach to estimate Norwalk-like virus contamination of oysters implicated in an outbreak. International J. Food Microbiol. 87, 107-112. 
Le Guyader, F., Haugarreau, L., Miossec, L., Dubois, E., Pommepuy, M., 2000. Three-Year Study To Assess Human Enteric Viruses in Shellfish. Appl. Environ. Microbiol., 66, 32413248.

Le Guyader, F.S., Loisy, F., Atmar, R.L., Hutson, A.M., Estes, M.K., Ruvoen-Clouet, N., Pommepuy, M., Le Pendu, J., 2006. Norwalk virus specific binding to oyster digestive tissues. Emerging and Infectious Disease. 12, 931-936.

Lipp, E.K., Kurz, R., Vincent, R., Rodriguez-Palacios, C., Farrah S.R., Rose, J.B., 2001. The effects of seasonal variability and weather on microbial fecal pollution and enteric pathogens in a sub-tropical estuary. Estuaries. 24, 238-258.

Loisy, F., Atmar, R.L., Le Saux, J.C., Cohen, J., Caprais, M.P., Pommepuy, M., Le Guyader, F., 2005. Use of rotavirus virus like-like particles as surrogates to evaluate virus persistence in shellfish, Appl. Environ. Microbiol. 71, 6049-6053

Miossec, L., Le Guyader, F., Haugarreau, L., Comps, M.A., Pommepuy, M., 1998. Possible relation between a winter epidemic of acute gastroenteritis in France and viral contamination of shellfish. J. Shellf. Res., 17, 1661-1664.

Monsen, N.E., Cloern, J.E., Lucas, L.V., 2002. A comment on the use of flushing time, resident time, and age as transport times scales. Limnol. Ocranography. 5, 1545-1553.

Noble, R.T., Lee, I.M., Schiff, K.C., 2004. Inactivation of indicators micro-organisms from various sources of faecal contamination in seawater and freshwater. J. Appl. Microbiol. 96, 464-472.

Orbi, A., Salomon, J.C., 1988. Dynamique de marée dans le golfe Normand-Breton. Oceanol. acta. $11,55-64$.

Plusquellec, A., Beucher, M., Prieur, D., Le Gal, Y., 1990. Contamination of the mussel, Mytilus edulis linneaus, 1758, by enteric bacteria. J. Shellfish Res. 9, 95-101

Pommepuy, M., Hervio-Heath, D., Caprais, M.P., Gourmelon, M., Le Saux, J.C., Le Guyader F., 2005. Fecal contamination in coastal areas: an engineering approach. In Oceans and Health: Pathogens in the Marine Environment. S. Belkin and R. R. Colwell Eds Springer, New York, USA. P. 331-359.

Pommepuy, M., Dumas, F., Caprais, M.P., Camus, P., Le Mennec, C., Parnaudeau, S., Haugarreau, L., Sarrette, B., Vilagines, P., Pothier, P., Kholi, E., Le Guyader, F., 2004. Sewage impact on shellfish microbial contamination. Water Sci. Technol. 50, 117-124. 
Rose, J.B., Dickson, L.J., Farrah, S.R., Carnahan, R.Pat. 1996. Removal of pathogenic and indicator microorganisms by full-scale water reclamation facility. Water Res. 30, 27852797.

Salomon, J.C., Pommepuy, M., 1990. Mathematical model of bacterial contamination of the Morlaix estuary (France). Water Res. 24, 983-994.

Simpson J.H. and Hunter, J.R., 1974. Fronts in the Irish Sea. Nature 250, 404-406.

Streets, B.M., Holden, P.A., 2003. A mechanistic model of runoff-associated fecal coliform fate and transport through a coastal lagoon. Wat. Res., 37, 589-608.

Thomann R.V., Mueller J.A., 1987. Principles of surface water quality modelling and control. Harper Collins Edts.

Turner, S.J., Lewis, G.D., 1995. Comparison of F-specific bacteriophage, enterococci, and faecal coliform densities through a wastewater treatment process employing oxidation ponds, Water Sci. Technol. 31, 85-89 


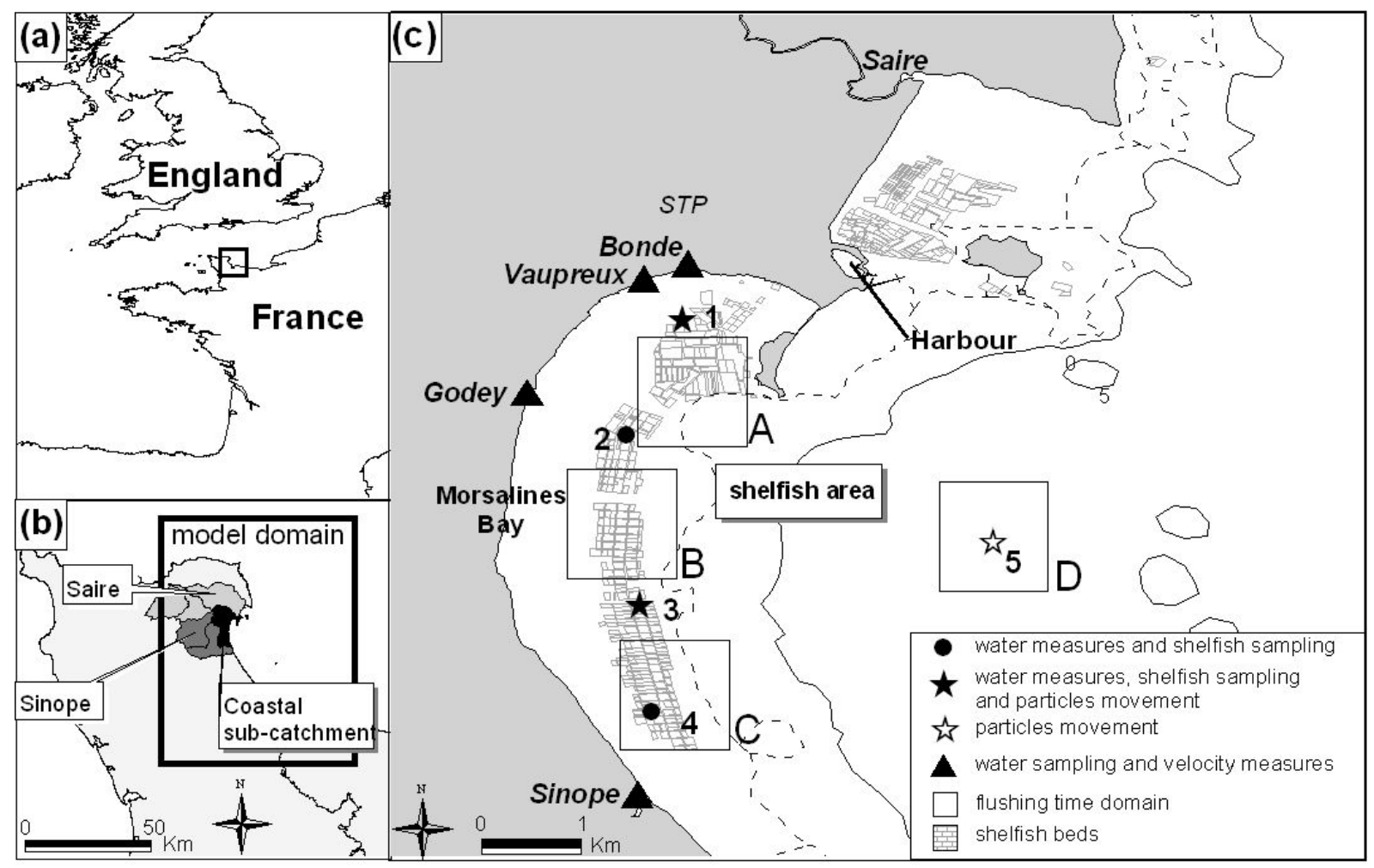

Figure 1: (a) Location of the study area ; (b) Domain included in the hydrodynamic model and the three sub-catchments (Saire, Sinope and coastal area sub-catchments); (c) Position of the tributaries, the shellfish sampling locations 1, 2, 3 and 4; and the domains A, B, C and D for flushing time calculation. 


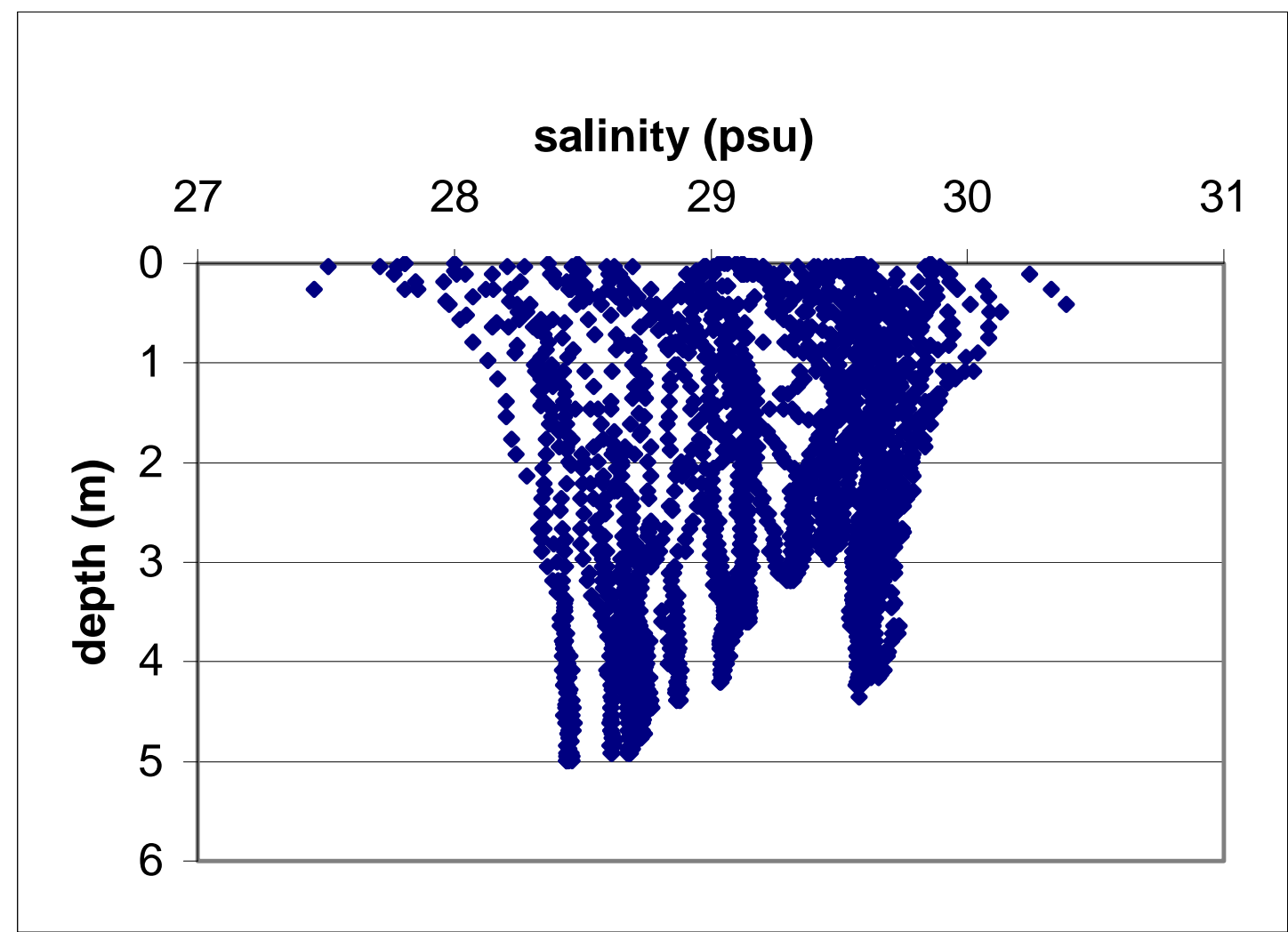

Figure 2: Depth versus salinity measured in field during a ten day period (location 3). 


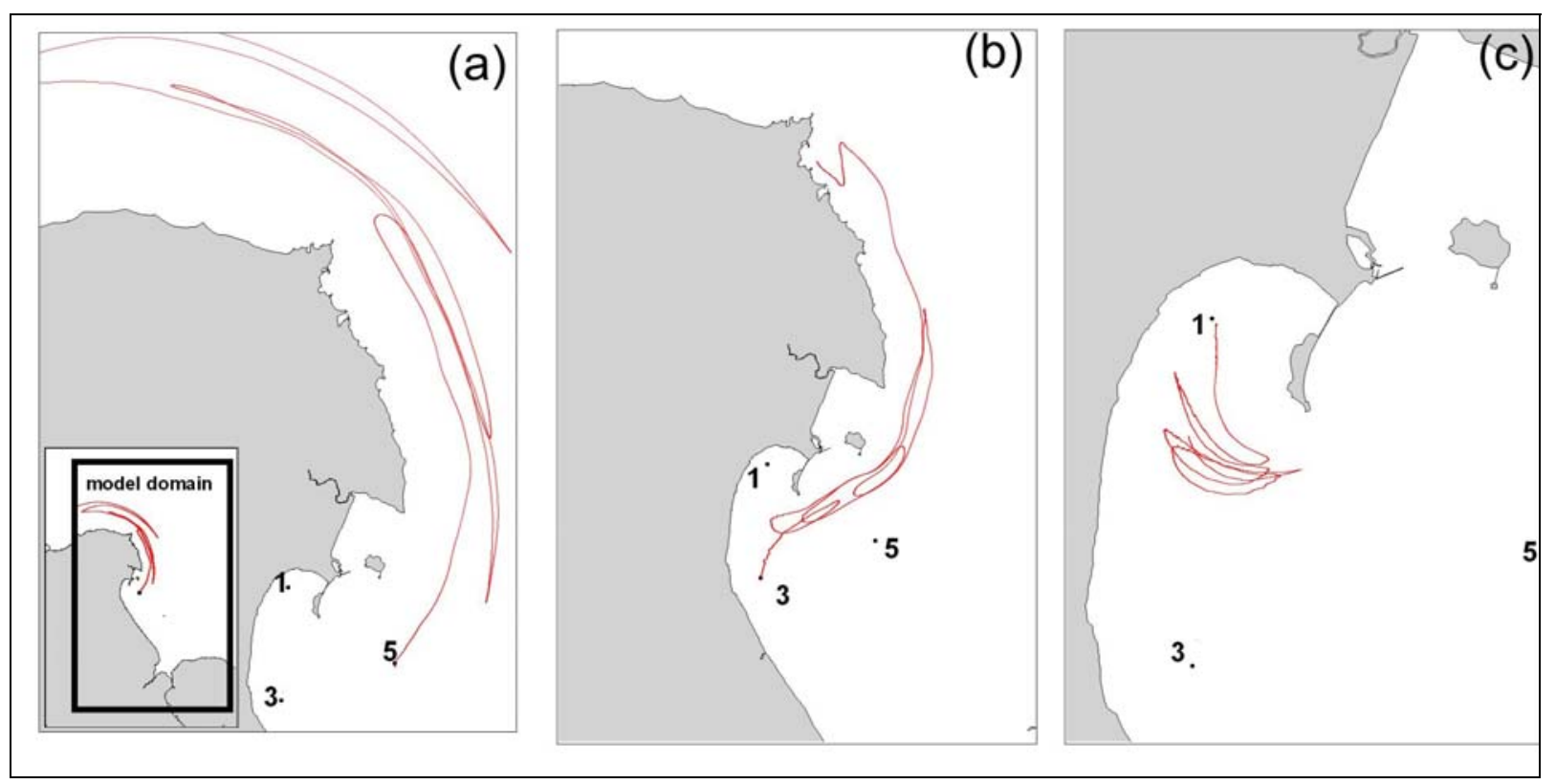

Figure 3: Simulation of particle movements in spring tides from location 5 (a), location 2 (b) and location 1 (c). Particles started in the model domain at high tide; end of the trajectories: high tide after four tidal cycles (2 days). 


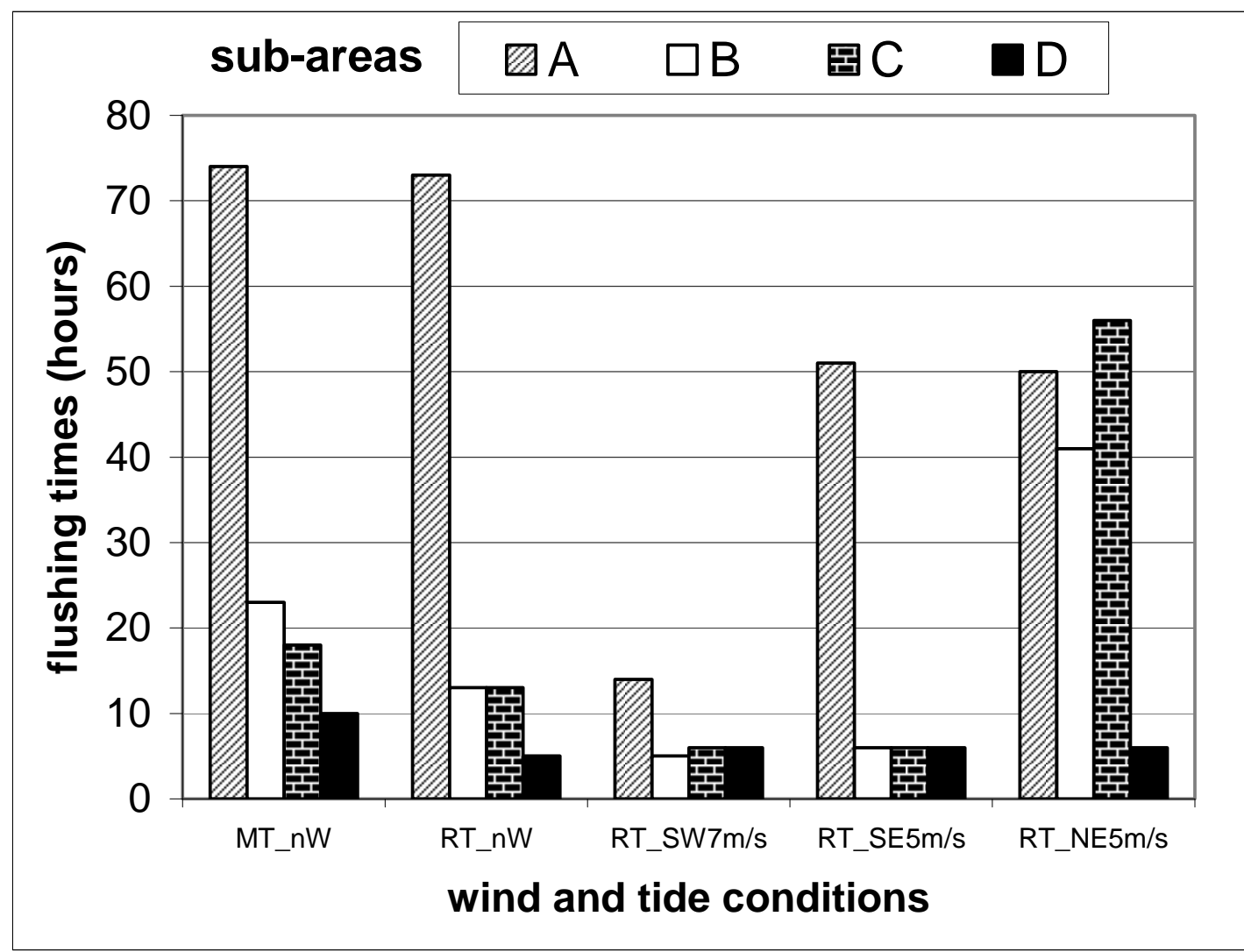

Figure 4: Flushing time $\left(T_{f}\right)$ in the different sub-areas, as a function of the tide and wind conditions:

MT: mean tide;

RT: real tidal simulation;

$\mathrm{nW}$ : without wind effect;

SW7m/s: south west $7 \mathrm{~m} / \mathrm{s}$;

SE5m/s: south east $5 \mathrm{~m} / \mathrm{s}$;

NE5m/s: north east $5 \mathrm{~m} / \mathrm{s}$; 


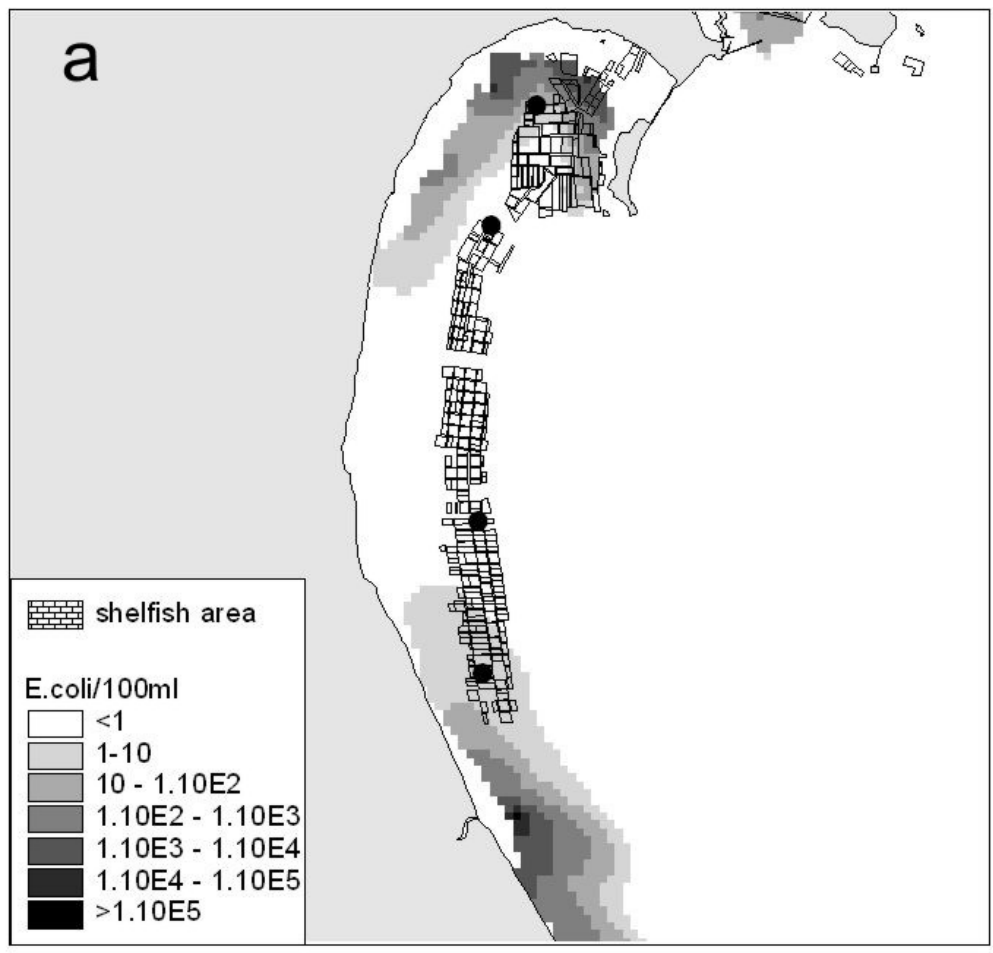

Fig 5a

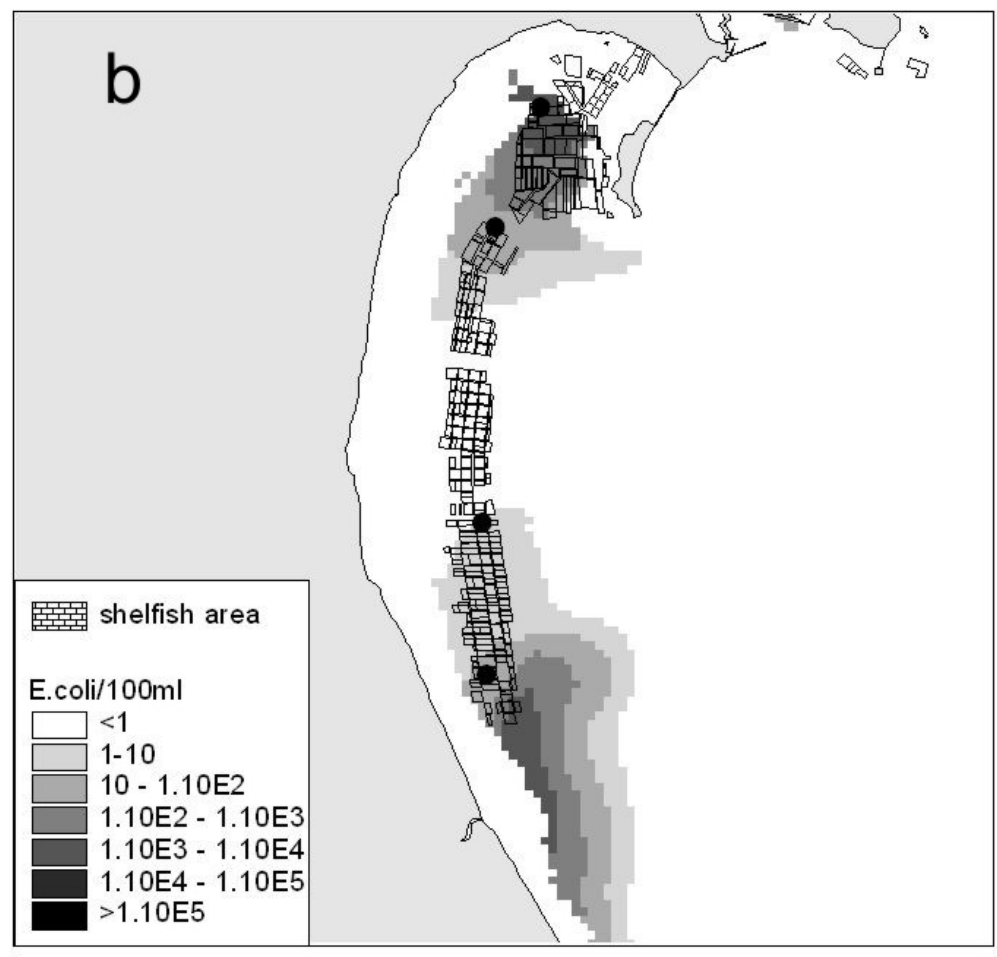

Fig. 5b 


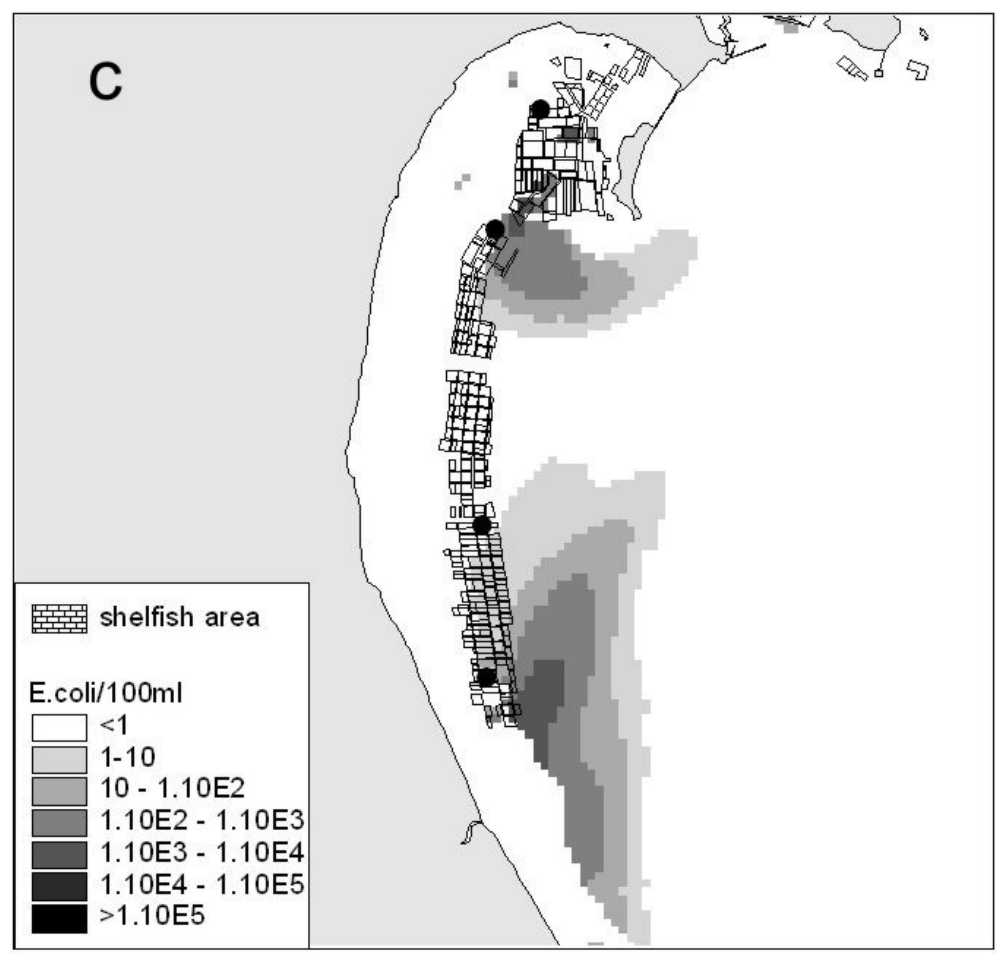

Fig 5c

Figure 5: Impact of rivers fluxes on water quality of shellfish growing areas (results are expressed in Escherichia coli/100ml): (a) High tide; (b) 3 hours after High tide ; (c) Low Tide 


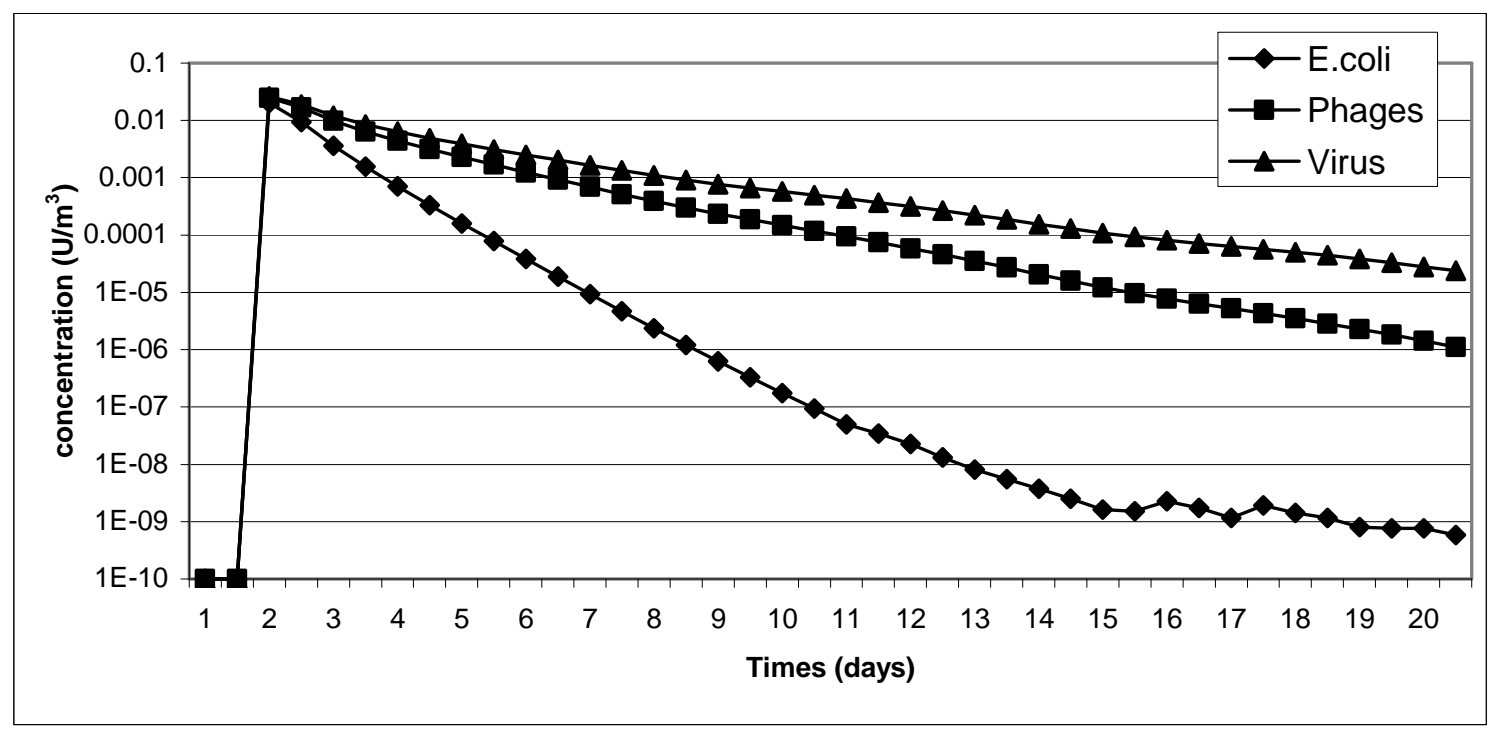

Figure 6: Simulation of variation in fecal contamination after a winter storm event (12 hours): E. coli, phage and astrovirus concentrations in water calculated at location 1. 
Table 1. Model input parameters and values

\begin{tabular}{|c|c|c|c|c|c|}
\hline \multicolumn{2}{|c|}{ Parameter } & Summer & Winter & & Comment \\
\hline \multirow{4}{*}{$\begin{array}{l}\text { Average }^{1} \\
\text { E. coli } \\
\text { flux }^{\mathrm{A}}\end{array}$} & Bonde & $3.6010^{10}$ & $6.6910^{10}$ & \multirow{4}{*}{$\mathrm{cfu} / \mathrm{m}^{3} / \mathrm{d}$} & \multirow{4}{*}{ Simulation for several days } \\
\hline & Vaupreux & $3.1010^{10}$ & $1.2610^{11}$ & & \\
\hline & Godey & $2.6010^{10}$ & $6.6010^{10}$ & & \\
\hline & Sinope & $3.0010^{11}$ & $1.4510^{12}$ & & \\
\hline \multirow{4}{*}{$\begin{array}{l}\text { Max. }^{2} \\
\text { E. coli } \\
\text { flux }^{\mathrm{A}}\end{array}$} & Bonde & & $1.3010^{12}$ & & \multirow{4}{*}{$\begin{array}{l}\text { Simulation during a } 12 \text { hour period } \\
\text { after } 3 \text { days of continuous average } \\
\text { fluxes }\end{array}$} \\
\hline & Vaupreux & ND & $7.0010^{12}$ & $\mathrm{cfu} / \mathrm{m}^{3} / 12 \mathrm{~h}$ & \\
\hline & Godey & & $4.2010^{11}$ & & \\
\hline & Sinope & & $5.8010^{13}$ & & \\
\hline \multirow{4}{*}{$\begin{array}{l}\text { Average }^{1} \\
\text { F-RNA } \\
\text { flux }^{B}\end{array}$} & Bonde & $1.8110^{09}$ & $9.0310^{09}$ & \multirow{4}{*}{$\mathrm{Pfu} / \mathrm{m}^{3} / \mathrm{d}$} & \multirow{4}{*}{ Simulation for several days } \\
\hline & Vaupreux & $3.8510^{09}$ & $2.5010^{10}$ & & \\
\hline & Godey & $9.2410^{08}$ & $6.4710^{09}$ & & \\
\hline & Sinope & $1.9510^{10}$ & $1.2610^{11}$ & & \\
\hline Max. $^{2}$ & Bonde & & $1.0910^{10}$ & & \multirow{4}{*}{$\begin{array}{l}\text { Simulation during a } 12 \text { hour period } \\
\text { after } 3 \text { days of continuous average } \\
\text { fluxes }\end{array}$} \\
\hline \multirow{3}{*}{$\begin{array}{l}\text { F-RNA } \\
\text { flux }^{B}\end{array}$} & Vaupreux & & $8.2610^{07}$ & $\mathrm{pfu} / \mathrm{m} / 12 \mathrm{~h}$ & \\
\hline & Godey & ND & $1.3310^{10}$ & & \\
\hline & Sinope & & $3.4510^{11}$ & & \\
\hline \multirow{4}{*}{$\begin{array}{l}\text { Max. } \\
\text { Astrovirus } \\
\text { flux }^{\mathrm{C}}\end{array}$} & Bonde & & $8.6710^{12}$ & & \multirow{4}{*}{$\begin{array}{l}\text { Simulation during a } 12 \text { hours } \\
\text { period }\end{array}$} \\
\hline & Vaupreux & & $9.4010^{13}$ & $\mathrm{G} / \mathrm{m}^{3} / 12 \mathrm{~h}$ & \\
\hline & Godey & ND & $1.5710^{13}$ & & \\
\hline & Sinope & & $1.0610^{14}$ & & \\
\hline \multicolumn{2}{|c|}{ T90 (E. coli) } & 24 & 48 & $\mathrm{~h}$ & \multirow{3}{*}{ Decay- rate coefficient } \\
\hline \multirow{2}{*}{\multicolumn{2}{|c|}{$\begin{array}{l}\text { T90 (phages) } \\
\text { T90 (astrovirus) }\end{array}$}} & 96 & 168 & h & \\
\hline & & ND & 336 & h & \\
\hline \multicolumn{2}{|c|}{$\begin{array}{l}\text { shellfish/water } \\
\text { concentration ratio }\end{array}$} & 30 & 30 & / & $\begin{array}{l}\text { Ratio used to calculate shellfish } \\
\text { concentration }\end{array}$ \\
\hline
\end{tabular}


Table 2: E. coli and phage F-RNA concentrations in the tributaries, Bonde, Vaupreux, Godey, and in the Sinope river during normal rainfall condition (rainfall $<10 \mathrm{~mm} \cdot \mathrm{d}^{-1}$ ) and overflow event (rainfall $>10 \mathrm{~mm} \cdot \mathrm{d}^{-1}$ ).

\begin{tabular}{|c|c|c|c|c|}
\hline & \multicolumn{2}{|c|}{ Rainfall $<10 \mathrm{~mm} \cdot \mathrm{d}^{-1}$} & \multicolumn{2}{|c|}{ Rainfall > $10 \mathrm{~mm} \cdot \mathrm{d}^{-1}$} \\
\hline $\begin{array}{l}\text { Tributaries } \\
\end{array}$ & E.coli $^{\mathrm{A}}$ & F-RNA ${ }^{B}$ pfu/100ml & E.coli & F-RNA \\
\hline and river & Mini -maxi & Mini-maxi & Mini -maxi & Mini-maxi \\
\hline Bonde & $3.510^{3}-7.210^{3}$ & $<10^{2}-3.410^{3}$ & $7.510^{3}-1.810^{5}$ & $6.310^{2}-3.910^{3}$ \\
\hline Vaupreux & $1.210^{2}-7.210^{3}$ & $<10^{2}-1.910^{3}$ & $8.110^{4}-1.110^{5}$ & $9.510^{2}-1.910^{3}$ \\
\hline Godey & $1.210^{2}-4.710^{4}$ & $<10^{2}-2.010^{2}$ & $3.010^{3}-1.110^{5}$ & $0.810^{2}-1.010^{2}$ \\
\hline Sinope & $3.610^{2}-7.710^{3}$ & $<10^{2}-2.310^{2}$ & $2.210^{2}-8.910^{3}$ & $3.010^{2}-3.610^{2}$ \\
\hline
\end{tabular}

${ }^{A}$ concentration expressed in cfu/100ml; ${ }^{B}$ concentration expressed in pfu/100ml, detection limit: $10^{2} \mathrm{pfu} / 100 \mathrm{ml}$.

Table 3: E. coli concentrations calculated (c) by the model and measured (m) in water and shellfish under normal conditions (rainfall $<10 \mathrm{~mm} . \mathrm{d}^{-1}$ ) during summer a) and winter b)

\begin{tabular}{|c|c|c|c|c|}
\hline a) & Site 1 & Site 2 & Site 3 & Site 4 \\
\hline Water c $^{A}$ & 2 & 0.7 & 0.02 & 0.4 \\
\hline Shellfish c ${ }^{\mathrm{B}}$ & 51 & 22 & 0.6 & 12 \\
\hline Shellfish $\mathrm{m}^{\mathrm{B}}$ & $\leq 100$ & $\leq 100$ & $\leq 100$ & $\leq 100$ \\
\hline
\end{tabular}

\begin{tabular}{|c|c|c|c|c|}
\hline b) & Site 1 & Site 2 & Site 3 & Site 4 \\
\hline Water c ${ }^{\mathrm{A}}$ & 8 & 5 & 1 & 8 \\
\hline Shellfish $c^{B}$ & 246 & 150 & 39 & 240 \\
\hline Shellfish $\mathrm{m}^{\mathrm{B}}$ & $\leq 100$ & $100-170 *$ & $100-150 *$ & $45-134 *$ \\
\hline
\end{tabular}

${ }^{A}$ concentration expressed in $\mathrm{cfu} / 100 \mathrm{ml} ;{ }^{B}$ concentration expressed in cfu/100g; detection limit for analyses $\leq 100 \mathrm{cfu} / 100 \mathrm{~g}$; ${ }^{*} \min -\max$ 
Table 4: F-RNA concentrations calculated (c) by the model in water and measured (m) in shellfish under normal conditions (rainfall $<10 \mathrm{~mm}^{-\mathrm{d}^{-1}}$ ) during winter.

\begin{tabular}{|c|c|c|c|c|}
\hline Winter & Site 1 & Site 2 & Site 3 & Site 4 \\
\hline Water c ${ }^{A}$ & 3 & 2 & 1 & 3 \\
\hline Shellfish $c^{B}$ & 102 & 69 & 27 & 75 \\
\hline Shellfish $\mathrm{m}^{\mathrm{B}}$ & 99-883* & $99-2075 *$ & $99-533 *$ & $99-290 *$ \\
\hline
\end{tabular}

Table 5: E. coli, F-RNA and astrovirus shellfish concentrations calculated (c) by the model and measured $(\mathrm{m})$ in field-caught shellfish after an overflow event (rainfall $>10 \mathrm{~mm} \cdot \mathrm{d}^{-1}$ ). Model simulation in winter and mean tide.

\begin{tabular}{|c|c|c|c|c|c|}
\hline & & Site 1 & Site 2 & Site 3 & Site 4 \\
\hline \multirow[t]{2}{*}{ E. $\operatorname{coli}^{A}$} & C & $4.910^{3}$ & $1.910^{3}$ & $5.110^{2}$ & $3.710^{3}$ \\
\hline & $\mathrm{m}$ & $1.310^{3}$ & $1.010^{2}$ & $1.110^{2}$ & $4.610^{2}$ \\
\hline \multirow[t]{2}{*}{ F-RNA $^{B}$} & C & $2.910^{2}$ & $1.310^{2}$ & $3.910^{1}$ & $1.010^{2}$ \\
\hline & $\mathrm{m}$ & $3.010^{2}$ & $1.010^{2}$ & $1.010^{2}$ & $3.910^{2}$ \\
\hline \multirow[t]{2}{*}{ Astrovirus $^{C}$} & $\mathrm{C}$ & $1.010^{5}$ & $610^{4}$ & $210^{4}$ & $210^{5}$ \\
\hline & $\mathrm{m}$ & $5.010^{4}$ & nd & nd & nd \\
\hline
\end{tabular}

